\title{
ТРАГЕДІЯ В. ШЕКСПІРА «РОМЕО І ДЖУЛЬЕТТА» І НАСТІЛЬНА ГРА М. ЕСКЬЮ «ІНТРИГИ ВЕРОНИ»: ІНТЕРМЕДІАЛЬНІ ВІДНОШЕННЯ
}

\author{
Данило Рега
}

Кандидат філологічних наук, доцент,

Кафедра світової літератури і порівняльного літературознавства, Прикарпатський національний університет імені Василя Стефаника (УКРАЇНА), 76018, м. Івано-Франківськ, вул. Шевченка, 57, e-mail: danylo.reha@pu.if.ua

\section{PЕФЕРАТ}

Мета. Статтю присвячено з'ясуванню інтермедіальних відношень між трагедією В. Шекспіра «Ромео і Джульєтта» та настільною грою М. Ескью «Інтриги Верони». Дослідницька методика. Для дослідження використано інтермедіальний метод аналізу. Його застосування дозволило проаналізувати рівень кореляції художнього тексту в його настільній реалізації. Це дало змогу з'ясувати рівень «існування» одного мистецького твору в іншому мистецькому оприявленні. Результати. У статті в межах компаративних студій здійснений аналіз інтермедіальних відношень між трагедією В. Шекспіра «Ромео і Джульєтта» та настільною грою М. Ескью «Інтриги Верони». 3' ясовано, що відношення між цим бінарним об'єктом $є$ вкрай тісними, а саме: сюжетні елементи трагедії, а також герої твору повністю перенесені в площину настільної гри. Звернено увагу на необхідності проведення подальших досліджень у даній сфері (як теоретичних, так і практичних). Наукова новизна. Попри достатню вивченість питання інтермедіальності як мистецького явища та методу аналізу, недослідженими $є$ інтермедіальні відношення між літературними творами та іншими видами мистецтва, зокрема настільними іграми. Практичне значення. Дана стаття може бути використана для подальшого провадження інтермедіальних досліджень у співвідношенні настільна гра-художній твір. Наукові результати дослідження можуть лягти в основу при написанні курсових, дипломних і інших наукових робіт.

Ключові слова. інтермедіальність, настільна гра, трагедія.

\section{THE TRAGEDY «ROMEO AND JULIET» BY W. SHAKESPEARE AND THE BOARD GAME «COUNCIL OF VERONA» BY M. ESKUE: INTERMEDIAL CONECTIONS}

\author{
Danylo Reha \\ Ph.D in Philology, Associate Professor, \\ Department of World Literature and Comparative Literary Criticism, \\ Vasyl Stefanyk Precarpathian National University (UKRAINE), \\ 76018, Ivano-Frankivsk, 57, Shevchenka str., \\ e-mail: danylo.reha@pu.if.ua
}

\begin{abstract}
Aim. The article deals with the clarification of the intermedial connections between the tragedy of W. Shakespeare «Romeo and Juliet» and the board game by M. Eskue «Council of Verona». Methods. In the article there has been applied intermediate approach. The using of this method has allowed to analyze the level of correlation of the creative work and its implementation in board game. It has allowed to find out the level of «existence» of one artistic work in another one. Results. In the article, within the framework of comparative studies has been made the analysis of intermedial connections between the tragedy of W. Shakespeare «Romeo and Juliet» and the board game by M. Eskue «Council of Verona». The article gives a detailed analysis about the binary object, its close connection between each other, namely: the plot elements of the tragedy, as well as the characters of the creative work completely moved to the plane of the board game. In the article attention has been drawn to the importance of further research in this field (both theoretical and practical). Scientific novelty. Despite
\end{abstract}


the sufficient knowledge of intermediality as an artistic phenomenon and as a method, are still not researched intermedial connections between creative works and other forms of art, including board games. The practical significance. The article may serve for the further intermedial researches in comparison of board games and creative works. The scientific results of the research may form the basis for writing course papers, diplomas and other scientific papers.

Key words. intermediality, board game, tragedy.

Починаючи з кінця XX століття порівняльне літературознавство значно розширило ареал власних розвідок, вийшовши на інтердисциплінарні зв'язки. Це дало можливість провадити дослідження у таких відношеннях, як література та політичне життя, література та культурологія, постколоніальні студії, екокритика, гей-лесбійські студії тощо.

Доволі тривалий час у компаративістиці відбуваються процеси виходу за власні рамки існування й доволі частих переходів у форми інтердисциплінарності, мультидисциплінарності, трансдисциплінарності та кросдисциплінарності. Одним із елементів інтердисциплінарності являється міжмистецьке порівняння або інтермедіальність, завданням якої є висвітлення зв'язків літератури з іншими видами мистецтва, визначення того, як один вид мистецтва реалізований у іншому виді мистецтва.

3 розвитком масової культури все більше різноманітних явищ входять у неї, одним із таких явищ $\epsilon$ культура настільних ігор.

Настільною грою визначається гра, яка в своїй суті містить елемент маніпуляції предметами (карти, фішки, жетони, кубики і т.д.), які можуть бути розміщені на будь-якій рівній поверхні або в руках гравців. Своїм корінням настільні ігри сягають IV-V тисячоліття до нашої ери. Ігри, такі як сенет, нарди, го та любо були відомі ще в стародавньому Сгипті, Індії і Китаї.

Все частіше, настільна гра стає важливою частиною національної культури (наприклад, грати в настільні ігри є традиційним елементом «хюге»данської філософії радіти життю [9].

Створюючи настільні ігри, автори черпають натхнення із різних сфер людського життя: кіно, телебачення, історії із реального життя, сни, історичні події і т. д. Одним із способів отримання натхнення, певної свіжої ідеї для настільної гри є література. Все частіше й частіше літературні твори переходять у форму настільної гри, в якій автори настільних проектів переносять сюжет, головних героїв, місце дії у формат настільної гри. Для кращого розуміння, подаємо таблицю, у якій вказані настільні ігри, а також їхня літературна основа:

\begin{tabular}{|l|l|l|}
\hline & Настільна гра & Літературний твір \\
\hline 1. & «Dune» & «Дюна» Ф. Герберта \\
\hline 2. & «Lord of the Rings» & «Володар перснів» Дж. Р. Р. Толкіна \\
\hline 3. & «Arkham horror» & Творчість Г. Ф. Лавкрафта \\
\hline 4. & «Council of Verona» & «Ромео і Джульєтта В. Шекспіра \\
\hline 5. & «The Fury of Dracula» & «Дакула» Б. Стокера \\
\hline 6. & «Beowulf: The legend» & $\begin{array}{l}\text { «Беовульф» - пам’ятка стародавнього } \\
\text { англосаксонського героїчного епосу. }\end{array}$ \\
\hline 7. & «Mr. Jack» & $\begin{array}{l}\text { Пригоди Шерлока Холмса, написані } \\
\text { А. К. Дойлем }\end{array}$ \\
\hline
\end{tabular}


Даний список можна продовжувати, адже, особливо, в останні роки література стала благодатним джерелом натхнення, запозичення і переробки для авторів настільних ігор. Такі елементи художнього твору, як герої, сюжети, антураж переходять у зовсім іншу площину, зовсім інше мистецтво. Саме тут і криється основна проблематика нашого дослідження: не існує розвідки, яка б звертала увагу на взаємозв'язок літературного твору та настільної гри як певного різновиду мистецтва. На дану проблему вказували В. Вольф [10], Дж. Еванс [1], І. Йоргенсен [2], І. Раєвскі [5]. У своїх працях вони різнобічно підходили до питань саме інтермедіальних відношень літератури та настільних ігор, однак тільки Дж. Еванс звертає увагу на практичну сторону порівняння, на противагу інших дослідників, які з теоретичної точки зору підійшли до даної проблеми. Окремо згадаємо й тих науковців, які вказували на можливості інтермедіальних зіставлень і намагалися окреслити методику проведення такого типу досліджень: У. Вайсштайн [8], В. Вольф [10], А. Махов [3], В. Просалова [4]. Так чи інакше, їхні тези можна звести до того, що інтермедіальні відношення варто шукати між літературним твором чи будь-яким іншим літературним явищем і такими видами мистецтва, як: кіно, музика, театр, образотворче мистецтво, скульптура, подекуди архітектура. Загальним словом - традиційні види мистецтва, генетично з часів Арістотеля. Однак, як бути з сучаснішими видами мистецтва? Ми впевнені в тому, що в XXI столітті інтермедіальні студії вийдуть за рамки «традиційності». Прикладом може слугувати лібература, в межах якої література набуває абсолютно нових властивостей [6].

Щоб практичніше підійти до питання інтермедіальності або в питанні визначення зв'язків одного художнього твору з іншим видом мистецтва, за об'єкт дослідження ми обрали трагедію В. Шекспіра «Ромео і Джульєтта» [7], а також настільну гру М. Ескью «Інтриги Верони». Маємо справу 3 тим, коли весь сюжет трагедії, а також герої твору перенесені в нову для себе площину й втілені через посередництво таких елементів, як жетони та карти. Назва настільної гри чітко вказує на місце, де відбувається дія драми В. Шекспіра італійське місто Верона, що є прямою алюзією.

Дія гри повністю повторює сюжет трагедії: дві веронські родини Монтеккі і Капулетті ворогують між собою, а Ромео і Джульєтта - представники цих сімей, відповідно, покохали один одного. У грі, окрім головних героїв, присутні й інші, яких зустрічаємо в трагедії В. Шекспіра, а саме: сеньйор Монтеккі, сеньйора Монтеккі, Бальтазар, Бенволіо, сеньйор Капулетті, сеньйора Капулетті, Тібальт, Самсон, брат Лоренцо, годувальниця Джульєтти, Меркуціо, Паріс, Ескал, Розаліна та аптекар.

Однією із основних цілей гри $є$, використовуючи механіки аукціону, драфту та менеджменту руки, зробити так, щоб Ромео і Джульєтта були разом і щоб ніхто з них не помер (однак в грі допустима смерть обох або когось із них). Мета гри корелюється із твором трагедії:

Хор: Кохання давнє впало, смертю зжерте,

Натомість юний пломінь запалав;

Ладен за першу він любов померти,

Та над усе Джульєтту покохав. 
Ромео любить, ця любов взаємна [7, с. 38]

Джульєтта: Згадай-но, хто ти: смерть тебе спіткає,

Як з наших хто тебе застане тут.

Ромео: Кохання принесло мене на крилах,

I не змогли цьому завадить мури;

Кохання може все і все здолає [7, с. 42]

Джульєтта ...що любий мій в руці стискає? Склянку,

Спорожнену, я бачу, до останку.

І смерть страшна отрута завдала...

Який скупий! Все випив! Не лишив

I краплі благодатної для мене,

Що помогла б мені піти за ним!

Я цілуватиму твої вуста...

Ще, може, трішки є на них трутизни, -

В підкріпленні цьому я смерть знайду...

...Тут рятівний кинджал!

Ось твої піхви!

Зостанься в них і дай мені умерти!.. [7, с. 119]

Як бачимо, сюжетні перипетії у трагедії між Ромео та Джульєттою перенесені на тло настільної гри, а смерть героїв у грі можлива за умови вживання отрути (зазначимо, що механікою гри допускається лікування героїв, відтак Ромео чи Джульєтта, отримавши жетон отрути, але маючи жетон ліків, уникають, таким чином, смерті) (див. рис. 1):

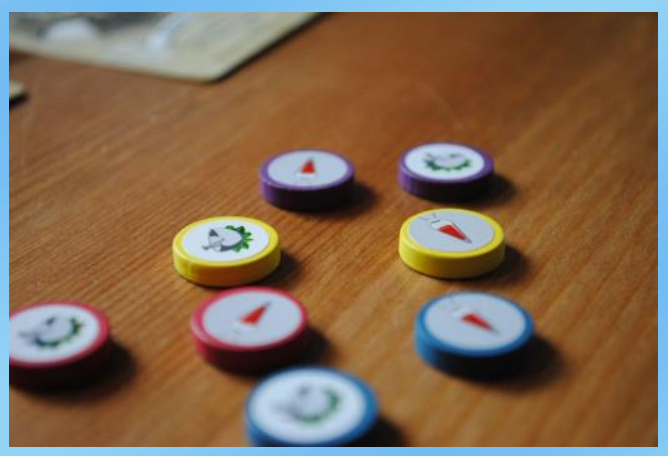

Puc. 1

Ще однією інтермедіальною особливістю є зображення Ромео та Джульєтти художниками гри Д. Лоудером, А. МакІвером і П. Уокеном (див. рис. 2)
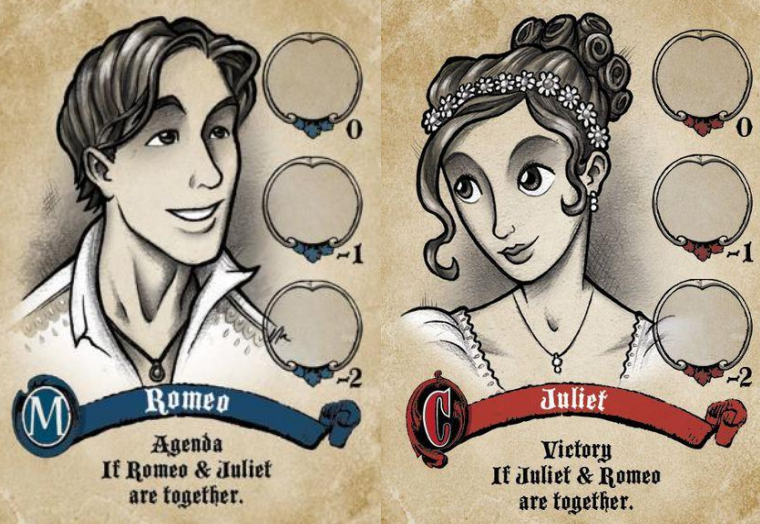

Puc. 2 
На малюнку персонажа Ромео видно, що він зображений у позитивному руслі, його окриляє любов до Джульєтти. Він у передчутті майбутнього спільного життя із нею. У творі, на відміну від статичності зображеного персонажа в грі, образ Ромео динамічний. Якщо спочатку Ромео сумний і його батько тривожиться 3 цього:

І замикається в своїх покоях;

Фіранками вигонить денне світло

I штучно створює цим темну ніч [7, с. 17]

То зустріч із Джульєттою перевернула світ Ромео. Він пізнає справжню любов: Померкли смолоскипи перед нею!
І світить вродою вона своєю
На щоках ночі - діамант ясний
У вусі мавра; скарб цей дорогий
І для землі, і для життя сія.
Вона - омріяна любов моя! [7, с. 34].

Вважаємо, що саме цей стан Ромео хотіли передати художники настільної гри.

Образ Джульєтти, як і образ Ромео в грі, змальований у радісному світлі, вона щаслива від любові. Так само образ Джульєтти в трагедії є динамічним, для якого характерними $є$ краса та розум, а згодом - рішучість і впертість:

Як ні, то присягни мені в коханні,

І більше я не буду Капулетті....

Так, мій Монтеккі, так, я нерозважна

I, може, легковажною здаюсь...

Повір мені, і я вірніша буду,

Ніж ті, що хитро удають байдужість [7, с. 44].

На нашу думку, художники настільної гри хотіли передати, в першу чергу, природню красу, розум і благородність Джульєтти.

Отже, бачимо, як одне мистецьке явище (літературний твір) знайшло своє втілення у іншому мистецькому явищі (настільній грі). Помітно, що сюжет, а також інші композиційні елементи перейшли в іншу мистецьку площину.

Дана розвідка жодним чином не претендує на всеохопність заявленої наукової проблеми, однак звертає увагу на можливість провадження майбутніх досліджень у сфері інтермедіальних відношень. Можемо бачити явище, коли літературний твір знаходить власне оприявлення, імплементацію у іншому, новому, як для зіставлення, виді мистецтва.

\section{ЛІТЕРАТУРА}

1. Evans J. Translating board games: multimodality and play. The Journal of Specialised Translation. 2003. No. 20. P. 15-32.

2. Jørgensen I. Media and games: an intermedial framework : 13th International Conference on the Foundations of Digital Games (Malmö, August 07-10. 2018). Malmö, 2018. P. 24-38.

3. Махов А. Е. Musica literaria : Идея словесной музыки в европейской поэтике. Москва : Intrada, 2005. $224 \mathrm{c}$.

4. Просалова В. Інтермедіальність як явище мистецтва і метод аналізу. Філологічні семінари. Київ, 2013. Вип. 16. С. 46-53. 
5. Rajewsky I. Intermediality, Intertextuality, and Remediation : A Literary Perspective on Intermediality. Intermédialités. 2005. No. 6, pp. 43-64.

6. Рега Д. Лібература: типологія, поетика : матеріали III Всеукраїнської наукової конференції (Дніпро, 25-26 травня, 2018). Дніпро, 2018. С.199-200.

7. Шекспір В. Ромео і Джульєтта. Дванадцята ніч, або Як собі хочете. Харків : Фоліо, 2008. $231 \mathrm{c}$.

8. Вайсштайн У. Взаємовисвітлення літератури та музики: сфера компаративістики? Сучасна літературна компаративістика: стратегії і методи : антологія. Київ : Видавничий дім «Києво-Могилянська академія», 2009. С. 391-410.

9. Wiking M. The Little Book of Hygge : The Danish Way to Live Well. London : Penguin Life, 2016. 288 p.

10. Wolf W. (Inter)mediality and the Study of Literature. CLCWeb: Comparative Literature and Culture. 2011. Vol. 13, issue 3. Дата оновлення : 01.05.2019. URL : https://docs.lib.purdue.edu/clcweb/vol13/iss3/2/ (дата звернення: 03.05.2019).

\section{REFERENCES}

1. Evans, J. (2013), "Translating board games: multimodality and play", The Journal of Specialised Translation, No. 20, pp. 15-32. (in English).

2. Jørgensen, I. (2018), "Media and games: an intermedial framework", 13th International Conference on the Foundations of Digital Games, Malmö, Sweden, August 07-10, 2018, pp. 24-38. (in English).

3. Makhov, A.J. (2005), Musica literaria: An idea of verbal music in European poetics [Musica literaria: Ideja slovesnoj muzyki v jevropejskoj poetikie], Intrada, Moscow, 224 p. (in Russian).

4. Prosalova, V.A. (2013), "Intermediality as a phenomenon of art and method of analysis" ["Intermedialnist yak javyshche mystetstva i metod analizu"], Filologiczni seminary, No. 16, pp. 46-53. (in Ukrainian).

5. Rajewsky, I. (2005) "Intermediality, Intertextuality, and Remediation: A Literary Perspective on Intermediality", Intermédialités, No. 6, pp. 43-64. (in English).

6. Reha, D. (2018), "Electronic literature: typology, poetics", Book of articles "SocioHumanitarian Sciences and the Contemporary Challenges", Vol. II, pp. 199-200. (in Ukrainian).

7. Shakespeare, W. (2008), Romeo and Juliet; Twelfth Night, or What You Will [Romeo $i$ Dziullietta; Dvanadtsiata nich abo Yak sobi khochete], Folio, Kharkiv. (in Ukrainian).

8. Weisstein, U. (2009), "Mutual coverage of literature and music: the matter of comparative studies?", in Nalyvaiko D.S. (Ed.), Modern comparative studies: strategies and methods, KyivMohyla academy, Kyiv, pp. 391-410. (in Ukrainian).

9. Wiking, M. (2016), The Little Book of Hygge: The Danish Way to Live Well, Penguin Life, London, 288 p. (in English).

10. Wolf, W. (2011), "(Inter)mediality and the Study of Literature", CLCWeb: Comparative Literature and Culture Vol. 13, issue 3, available at: https://docs.lib.purdue.edu/clcweb/vol13/iss3/2/ (in English). 